\title{
Macroeconomic Considerations and Motives of Sovereign Wealth Funds Activity
}

\author{
Dariusz Urban ${ }^{1}$
}

ABSTRACT

Sovereign wealth funds are entities regarded as an institutional innovation in the international financial market. Due to the nature of the ownership rights, the investment activity of such entities is still highly controversial. Objections against sovereign wealth funds included the alleged extraeconomic goals of their activity.

This article attempts to show that the establishment development and operation of sovereign wealth funds are determined by economic factors. The study presents a description of the international monetary system and the motives for building foreign exchange reserves by countries. It has been evidenced on the basis of the most recent data that some countries have reserves considerably exceeding the level regarded as optimal for the economy. The article presents benefits for the economy from the use of sovereign wealth funds to manage excessive foreign exchange reserves.

KEY WORDS: $\quad$ sovereign wealth funds, foreign exchange reserves, international monetary system

JEL Classification: E 42, F 33

1 University of Lodz, Poland

\section{Introduction}

Sovereign wealth funds are state-owned entities, the basic task of which consists in the allocation of the country's financial reserves. These entities are regarded as an institutional innovation in the international financial market. As opposed to the policy of investing foreign exchange reserves conducted by central banks, a policy assuming a low risk and a low return rate as well as a narrow range of assets purchased, sovereign wealth funds implement investment strategies aimed at achieving higher return rates than before with a simultaneous acceptance of higher risk connected with it. Moreover, investment activity conducted by these entities in domestic and international markets significantly diversifies the asset portfolio, into which

Corespondence concerning to this article should be addressed to: durban@uni.lodz.pl currency reserves of a given country are transferred. Global activity of sovereign wealth funds, which is conducted on a large scale and combined with the lack of even basic information about the operation of these entities, on numerous occasions lead to a situation, in which the activity of sovereign wealth funds is often perceived from the angle of political goals. On behalf of the countries, these entities may fulfil have been established.

The aim of this study is to present the economic conditions of the establishment and development of the sovereign wealth funds. This article is aimed at disputing the claim that the establishment and activity of these entities are motivated by extra-economic conditions, which constitutes one of the fundamental objections brought forward against these entities. The discussion will present the influence of key macroeconomic factors determining the development of such funds, which, in the author's opinion, should include 

left at the individual countries' discretion. However, the lack of a defined and commonly accepted reserve currency introduced a new risk into the world's monetary system. The system of collective reserve currencies - despite the fact that the majority of the countries still chose the dollar - forced the countries to increase their foreign exchange reserves significantly
(Fig. 1.). They became a method of coping with foreign exchange fluctuations and external imbalances. A particularly distinct increase in the reserves, which usually had the form of government bonds, occurred in developing countries and in rising markets (Ping \& Chao, 2009: 8-11).

Figure 1. The level of foreign exchange reserves in the years 1960-2009 (in billions US dollars)

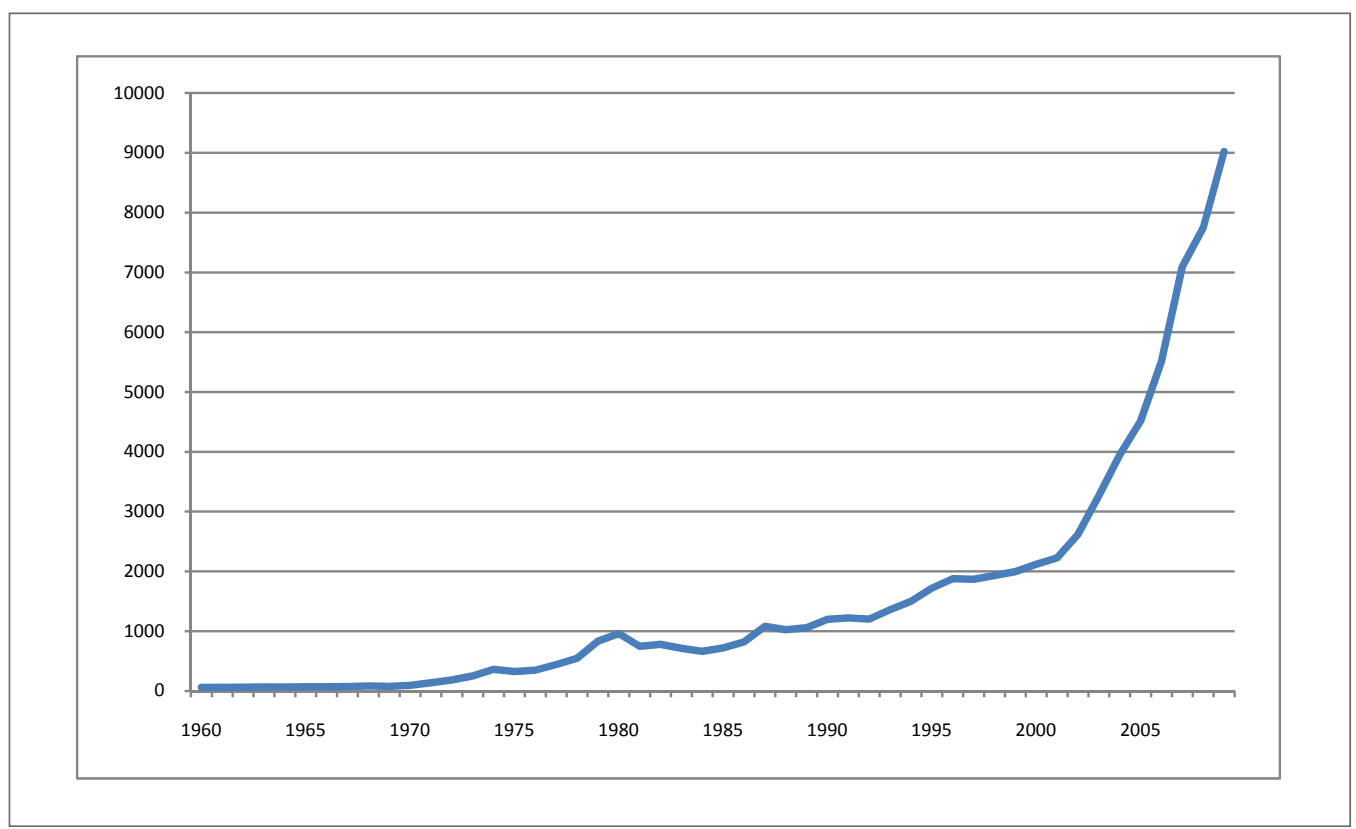

Source: : the author's own work on the basis of the World Bank data.

Visco pinpoints that the international monetary system, which has been in operation since the suspension of dollar for gold exchangeability (the actual fall of the Bretton Woods system), is not really a system, but the outcome of open preferences of individual countries as regards the foreign exchange rate, with very small or virtually absent international supervision at the same time. The regime of fixed exchange rates has never been replaced with a system of floating rates, and what we have now can be considered a hybrid solution. In practice, most countries' foreign exchange policy has been characterised by fear of fluctuations and the resultant high level of foreign exchange interventions for the past 35 years (Visco, 2010: 74-75). A description of the currently applicable agreements in the area of international finance as a non-systemic solution can also be found in the latest studies by employees of the International Monetary Fund (Mateos y Lago, Duttagupta \& Goyal, 2009: 5).

A different point of view on the operation of the present-day international monetary system is presented by Dooley, Folkers-Landau \& Garber (Dooley Folkerts-Landau \& Garber, 2004; Dooley, Folkerts-Landau \& Garber, 2009). Namely, they suggest that the system of current agreements and connections in the area of foreign exchange rates is a simple continuation of the Bretton Woods system - to distinguish it from the original system, they call it Bretton Woods II or the re- 

den stop of foreign capital inflow to a given economy and/or a simultaneous strong capital outflow from this economy. Nearly 100 cases of sudden stops have been identified in the past 25 years and the average costs incurred by the affected economy for this reason have been estimated at approx. 10\% GDP (Hutchison, Noy \& Wang, 2010: 973-974).

A significant increase in the reserves of these countries is perceived as a form of protecting the country against the potential crisis (Table 1). Realizing that the loss of access to financial markets is a drawback of financial globalisation and that financial tools, which can be used in the case of a sudden stop of the capital inflow (or its violent outflow), are limited, these countries treat these reserves as a kind of war chest (Durdu, Mendoza \& Torrenes, 2009: 194). An increase in a country's financial liquidity by accumulation of foreign exchange reserves is this country's self-insurance mechanism in the event of crises in world markets (Alfaro \& Kanchuk, 2009: 23).

Table 1. Mean values of the characteristics of the countries investigated and the test for equality of means

\begin{tabular}{|c|c|c|c|c|}
\hline \multirow[b]{2}{*}{ Country } & \multirow[b]{2}{*}{$\begin{array}{l}\text { Year of crisis } \\
\text { occurrence }\end{array}$} & \multicolumn{3}{|c|}{ Foreign exchange reserves as GDP \% } \\
\hline & & $\begin{array}{c}\text { Before the crisis (from } \\
1985 \text { to the year preceding } \\
\text { the crisis) }\end{array}$ & $\begin{array}{c}\text { After the crisis (from the } \\
\text { year after the crisis to the } \\
\text { year 2004) }\end{array}$ & $\begin{array}{l}\text { Change in the } \\
\text { reserve level }\end{array}$ \\
\hline \multirow{2}{*}{ Argentina } & 1994 & 3.20 & 8.65 & +5.42 \\
\hline & 2001 & 5.04 & 11.54 & +6.51 \\
\hline Brazil & 1998 & 4.36 & 7.65 & +3.30 \\
\hline Chile & 1998 & 16.93 & 20.49 & +3.57 \\
\hline Columbia & 1998 & 9.42 & 12.21 & +2.97 \\
\hline Ecuador & 1999 & 7.35 & 3.89 & -3.46 \\
\hline Hong-Kong & 1998 & 34.16 & 68.85 & +34.69 \\
\hline Indonesia & 1997 & 6.53 & 18.69 & +12.17 \\
\hline South Korea & 1997 & 5.03 & 21.26 & +16.23 \\
\hline Mexico & 1994 & 4.64 & 7.29 & +2.65 \\
\hline Malaysia & 1997 & 25.18 & 39.54 & +14.36 \\
\hline Pakistan & 1998 & 1.90 & 8.51 & +6.61 \\
\hline Peru & 1998 & 9.25 & 16.66 & +7.41 \\
\hline Philippines & 1997 & 6.05 & 16.69 & +10.65 \\
\hline Russia & 1998 & 3.05 & 12.46 & +9.41 \\
\hline Thailand & 1997 & 14.84 & 28.01 & +13.17 \\
\hline Turkey & 2001 & 5.67 & 13.57 & +7.90 \\
\hline Uruguay & 2002 & 7.18 & 20.06 & +12.87 \\
\hline
\end{tabular}


The self-insurance motive for the accumulation of reserves is connected with the phenomenon of adjusting the reserve level in a group of countries. The issue of the influence of the foreign exchange reserve level accumulated by the adjacent countries on the level of the reserves accumulated by a given economy was first touched upon by Fritz Machlup (1966). He compared the behaviour of economies in this respect to the behaviour of his wife regarding the accumulation of new clothes in her wardrobe: the appearance of a neighbour wearing new clothes each time conditioned subsequent purchases of clothes by his wife. As regards economies, the Machlup hypothesis (keep up with the Joneses, Mrs. Machlup wardrobe hypothesis) means that the target level of a country's foreign exchange level is influenced by the size of reserves accumulated by the adjacent countries. The latest empirical verification of this hypothesis was presented by Cheueng \& Sengupta. They proved that in the years 1980-2007, the level of foreign exchange reserves accumulated by countries, such as Argentina, Bolivia, Brazil, Chile, Columbia, Ecuador, Mexico, Peru, Uruguay and Venezuela, can be accounted for (apart from other variables) by the phenomenon of adjusting the reserves of a given country to the reserve level in the region (Cheung \& Sengupta, 2010). Similar studies confirmed the occurrence of the afore-mentioned phenomenon among a group of Asian countries (Cheung \& Qian, 2009), including China, India, Indonesia, Japan,
South Korea, Malaysia, Philippines, Singapore, Taiwan and Thailand. The authors provided an empirical confirmation that the level of foreign exchange reserves in the years 1980-2004 was adjusted to their general level in the group. The appearance of an additional dollar in the form of reserves from one of the countries resulted in an increase of the foreign exchange reserves in the group by 60 cents. This effect was even stronger during the period following the Asian crisis, i.e. after 1997.

Another factor responsible for the increase in the global reserve level is the application of growth strategies based on exports. According to this concept the accumulation of reserves by some Asian countries is a by-product of this kind of growth strategy. However, as Aizenman \& Lee (2007) pointed out, this factor determining the size of foreign exchange reserves is weaker than the demand caused by the self-insurance motives.

The research conducted by Eichengreen \& RacoGarcia showed that a further increase in the capital mobility and a rise in capital flow connected with it. This will result in more countries abandoning the unstable foreign exchange rate mechanisms (various types of floating exchange rates and soft variations of fixed exchange rates) to adopt floating exchange rates (Eichengreen \& Raco-Garcia, 2006: 416). This can further enhance the tendency towards accumulation of foreign exchange reserves by countries.

Figure 2. Increase in foreign exchange reserves in selected countries in the years 1999-2009 (in billions of US dollars)

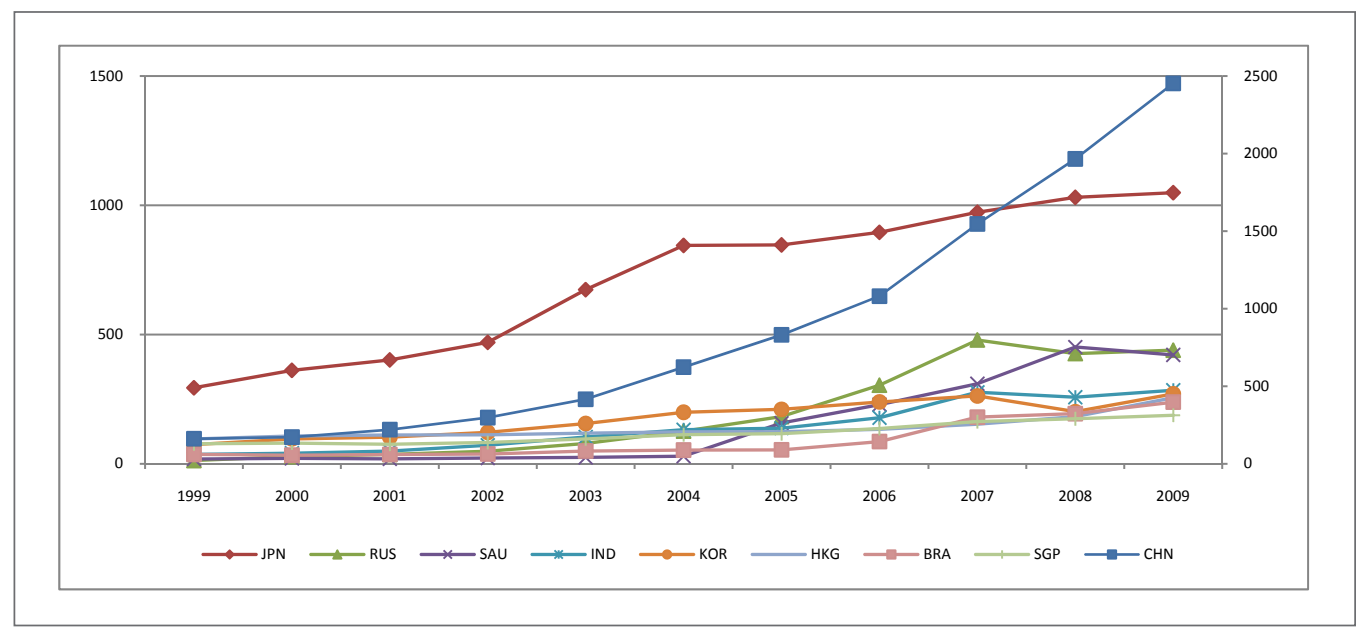

Source: the author's own work on the basis of the World Bank data. 
The data presented in Fig. 2 prove that in the group of countries under analysis, an increase in the value of the accumulated reserves is taking place. The fact that the nine countries mentioned below held $62 \%$ of the global reserves in 2009 deserves to be emphasised, which shows a significant concentration of this phenomenon. China is the leader in this area (the righthand side in the figure), as it holds twice as much foreign exchange reserves than Japan, which is ranked second. A similar scale of disproportion occurs between Japan and Russia and Saudi Arabia, which follow it in the ranking.

In summary, it must be stressed that the motives for accumulating foreign exchange reserves can be basically divided into two groups. The first of these includes self-insurance, precautionary motives, which come down to treating reserves as a specific form of insurance of a country participating in the global economic system against the risk induced by such a developmental strategy. The other group, on the other hand, encompasses competitive, mercantile motives where reserves are used for the achievement of economic objectives - to achieve the competitiveness of exports.

\section{Models of Foreign Exchange Reserves}

Due to the differences occurring between economies, there is no index, which would precisely describe the optimal or sufficient levels of reserves which should be accumulated by a given country. The following measures concerning the appropriate reserve level an economy should have are commonly accepted and the most frequently mentioned in the literature on foreign exchange reserves (Green \& Torgerson, 2007: 3):

- Reserves in relation to short-term debt or the Greenspan-Guidotti rule. According to this approach, the size of reserves in developing countries should make it possible to cover the debt with the debt repayment time limits shorter than a year. At the same time, this is the most frequently used indicator of an economy's sensitivity to a foreign exchange crisis.

- Reserves in relation to the monetary aggregate M2. In the approach proposed by Wijnholds \& Kapteyn, M2 depends on the foreign exchange regime, the level of reserves considered to be appropriate for a country ranges from 5 to $20 \%$. The justification of the use of this point of view is an economy's sen- sitivity to capital withdrawal and the trust to the local currency value can be measured by the monetary reference to the level of reserves.

- Reserves to the size of imports. The index considered to be optimal for countries with the low income level and at the same time, those without full access to international capital markets. The most frequently quoted reference level is the level of reserves making it possible to cover three months of exports.

- Foreign exchange reserves to GDP. This measure is the least economically justified, as the gross domestic product is not a measure of risk, which could take place in the case of crisis. Therefore, there are no grounds to compare the level of reserves to the gross national product in a given country.

On the basis of the data presented in Fig. 3, it can be concluded that in the analysed countries, the level of the reserves they had accumulated did not exceed the level of total external debt in 2008. Brazil is the only exception here, where the foreign exchange reserves to total debt ratio was at the level of $76 \%$ in the last year of the analysis. It shows that the reserve level defined by the Greenspan-Guidotti rule was significantly exceeded. In the case of Algeria (the scale on the right-hand side of the diagram), the reserves are 27 times higher than this country's current total debt. The data presented in Fig. 4, on the other hand, prove that, except for Russia in 1999, the reserves of all countries exceeded the reference level defined by the value of three months of imports in the period under analysis (market with a dotted line in the diagram). Saudi Arabia's foreign exchange reserves were sufficient to cover the equivalent of 28 months of imports in 2008.

Beck \& Fidora made an attempt to assess the size of excessive reserves accumulated by various countries in 2007. In the method which they adopted, they determined the excessive reserve level as the difference between the total reserves and one of the two values considered to be the benchmark: three months of import value or the short-term debt value. According to their calculations, the global value of excessive foreign exchange reserves accumulated in the world's economy in 2007 is at the level of 3023 billion USD (Beck \& Fidora, 2008: 14).

Keeping excessive reserves by developing countries is expensive for two reasons. Firstly, these funds could 
Figure 3. The level of foreign exchange reserves in selected countries in relation to the total external debt in the years 1999-2008 (in \%)

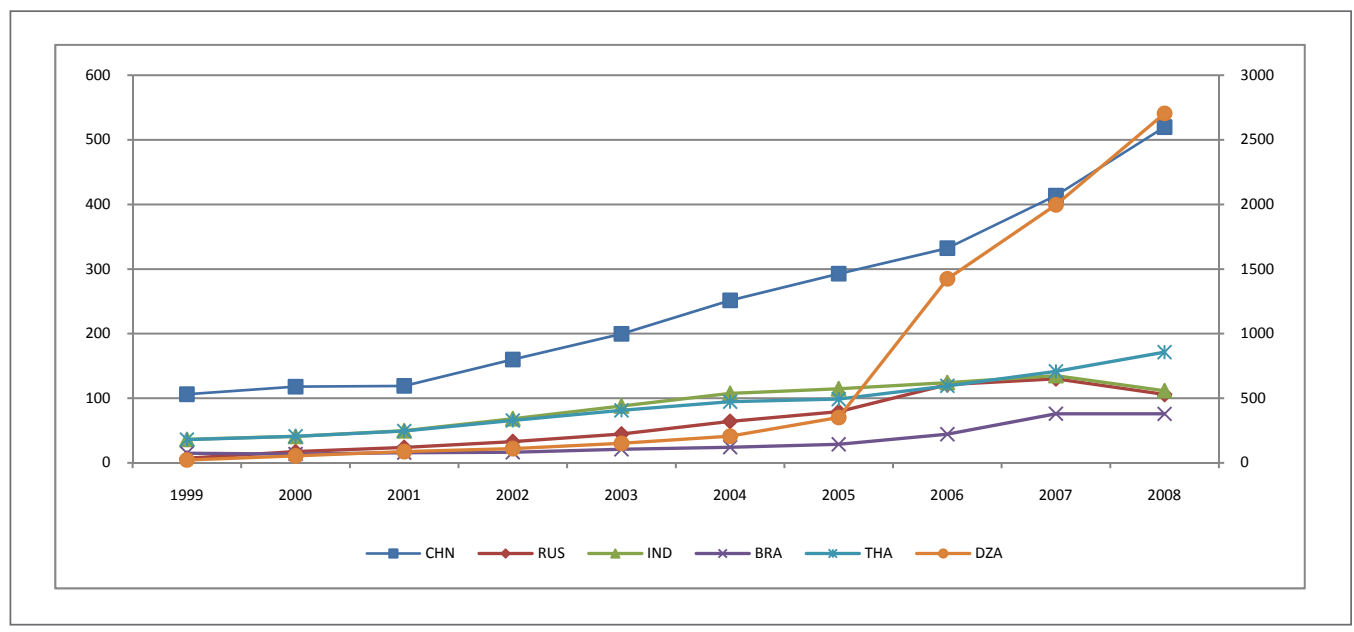

Source: the author's own work on the basis of the World Bank data.

Figure 4. The relation of the total foreign exchange reserve value to the monthly imports in selected countries in the years 1999-2008 (monthly imports cover)

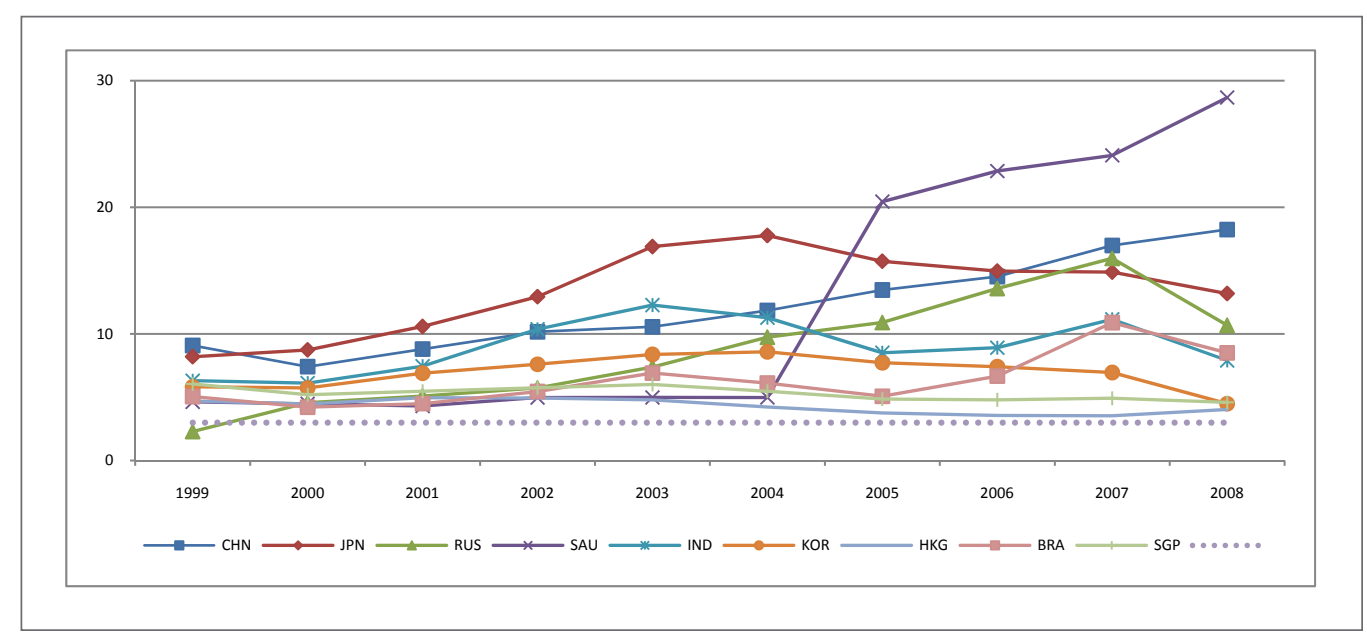

Source: the author's own work on the basis of the World Bank data.

be allocated to more effective investment projects. Secondly, the occurrence of the alternative cost is connected with holding reserves. Assuming that a given country has external debt, the difference between the rate, at which funds are borrowed in international markets, and the return rate achieved from the allocation of reserves, represents the cost of lost opportunities, which is incurred by a given economy in connection with keeping the reserves (Akdogan, 2010: 3). The cost of keeping excessive reserves by developing countries was estimated by Rodrick at the level of one percentage point of the GDP (Rodrick, 2006: 9). In the context of the costs of keeping excessive reserves, it needs to be mentioned that the competition of countries in accu- 
mulating foreign exchange reserves accounted for by Machlup leads to an increase in the demand for these reserves over the level, which can be explained in terms of economic factors. The consequence of such a strategy of competition between the countries is an increase in the costs incurred by these countries in connection with keeping the reserves (Cheung \& Sengupta, 2010: 12). On the other hand, Levy-Yeyati proves that an increase in the reserves by one percentage point lowers the costs connected with the financing of external debt by 0.5 percentage point. In this case, the reserves are treated as a form of indirect security on the loan granted, which makes it possible to reduce the risk bonus - expected by investors financing a given country's debt (Akdogan, 2010:5).

The data presented above make it possible to conclude that the level of reserves, which are currently kept by numerous countries, considerably exceeds the indexes regarded as optimal. Considerable alternative costs connected with the possession of excessive reserves make it necessary to manage the reserves held by the individual countries in a more effective way than before. It becomes possible owing to the application of innovative investment tools, i.e. sovereign wealth funds.

\section{Sovereign Wealth Funds as Tools of Effective Management of Excessive Foreign Exchange Reserves}

Sovereign wealth funds are defined as special investment funds created by a state or state-owned entities with the main task consisting in long-term asset investment outside the given country (IMF, 2007:45). Two basic sources of funds, which are available to these entities, are revenues from the sales of natural resources and surpluses achieved in trade exchange. These funds are a relatively new phenomenon in the world's economy. Their greatest development took place in the years 2000-2010, where half of the 50 largest funds of this type were established. The remaining funds were established in the years 1990-1999 (17\%) and before the year 1990 (27\%)(IFSL, 2011:4). The establishment and development of sovereign wealth funds were discussed in D. Urban's article, "Sovereign wealth funds - a new challenge for corporate supervision" (Urban, 2010: 40-43). At present, this category of investment entities encompasses 53 funds (www. swfinstitute.org, of 25.06.2011), most of which comes from Asia and the Near East 37\% and 36\% respectively (IFSL, 2011:4). The data presented in the latest study by Monitor Group show that the most direct investments of these funds were connected with the financial sector, over $60 \%$ of which took place in BRIC countries, while 35\% in OECD countries (Monitor Group, 2011:12-17). Fundamental macroeconomic benefits for a country with such funds will be presented below.

The consequences of a capital inflow to the economy (exceeding the outflow stream or exceeding the economy's absorption capabilities) are a commonly known issue. They generally include: inflation, speculative bubbles, appreciation of the foreign exchange rate, excess liquidity and imbalance of the financial sector. This forces the country's monetary authorities to take neutralising/sterilising actions. Thus, the growing stream of capital inflow makes it necessary to intervene on a larger scale, which, in turn, is conditioned by having larger and larger reserves, which can be used for sterilisation. The emergence of sovereign wealth funds has created an alternative possibility of managing the inflowing capital stream. Thus, it became possible to transfer capital abroad and to allocate it to foreign assets and not by means of intervening in the domestic monetary market. There are two kinds of benefits from this activity. Firstly, a similar goal as in the case of domestic sterilisation can be achieved - i.e. inflation prevention and prevention of speculative bubbles as well as being able to keep the competitiveness of the economy, owing to the foreign exchange rate stabilisation. Secondly, foreign sterilisation, which is possible owing to the existence of sovereign wealth funds, allows for allocation of domestic capital to assets with a higher return rate. According to Areaza, Castilla \& Fernandez, sovereign wealth funds are an alternative to sterilisation implemented by monetary authorities. Prevention of negative consequences of capital inflow is possible by, among other things, foreign exchange interventions, changes of mandatory reserves in banks or taxing the inflowing capital. Such activities are always costly and difficult to perform in the long run (Areaza, Castilla \& Fernandez, 2009: 26).

As presented in the study by the International Monetary Fund (IMF, 2008: 4), sovereign wealth funds offer numerous financial and economic benefits for the founding countries. These include facilitation connected with 

international foreign exchange system, which makes it necessary for the countries to hold considerable foreign exchange reserves. These reserves significantly exceed the indices considered to be optimal for the countries under analysis. It has been shown in the article that sovereign wealth funds can be an alternative form of foreign exchange reserve management.

The analysis conducted in this article proves that the development of institutional entities called sovereign wealth funds is determined by economic factors. In the first place, they include the necessity of managing the inflowing capital to prevent it from causing negative consequences for the economy in the form of excess liquidity, speculation and foreign exchange rate appreciation. Secondly, the objectives of these entities include the minimisation of the alternative cost resulting from holding considerable capital by transferring it to other assets ensuring the highest possible return rate.

It also needs to be underlined that the architecture of the global finance in its current condition will probably continue to generate global imbalance, which will result in a further increase in the level of foreign exchange reserves accompanied by a growing interest in alternative forms of investing these reserves. Sovereign wealth funds are innovative tools in this area. Their activity makes it necessary to redefine the existing paradigms concerning the allocation of foreign exchange reserves. These entities can be treated as specific substitutes for national monetary authorities, supporting central banks in the achievement of monetary goals in the domestic markets, and, on the other hand, as important entities of the global financial market, the operation of which ensures the countries of their origin an effective way of managing excessive foreign exchange reserves.

\section{References}

1. Aizenman, J., Lee, J. (2007). International reserves: Precautionary versus mercantilist view, hypothesis and evidence, Open Economies Review, 18(2), 191214.

2. Akdogan, K. (2010). Foreign exchange reserves in a credit-constrained economy. Birkbeck Working Papers in Economics \& Finance, 1014.

3. Alfaro, L. \& Kanchuk, F. (2009). Optimal reserve management and sovereign debt. Journal of International Economics, 77(1), 23-36.
4. Areaza, A., Castilla, L. \& Fernandez C. (2009). The coming of age of sovereign wealth funds: Perspectives and policy issues within and beyond borders. Global Journal of Emerging Market Economies, 1(1), 25-41.

5. Beck, R. \& Fidora M. (2008). The Impact of Sovereign Wealth Funds on Global Financial Markets. ECB Occasional Paper Series, No.91.

6. Cehajic, S. (2009). Sovereign Wealth Funds: Contingent Risks and a Laissez-Faire Approach Complemented With a"Just-in-Case" Reactive Regulatory Framework. (October 1, 2009). Available at SSRN: http://ssrn.com/abstract $=1494291$

7. Cheung, Y.W. \& Qian, X. (2009). Hoarding of International Reserves: Mrs Machlup's Wardrobe and the Joneses. Review of International Economics, 17(4), 824-843.

8. Cheung, Y.W. \& Sengupta R. (2010). Accumulation of reserves and keeping up with the Joneses: The case of LATAM economies. International Review of Economics and Finance, 20(1), 19-31.

9. Costabile, L. (2009). Current global imbalances and the Keynes Plan. A Keynesian approach for reforming the international monetary system. Structural Change and Economic Dynamics, 20(2), 78-89.

10. D`Arista, J. (2009). The evolving international monetary system. Cambridge Journal of Economics, 33(4), 531-538.

11. De Larosière, J. (2009). Report of the High-Level Group on Financial Supervision in the EU. Brussels: The de Larosière Group.

12. Deutsche Bank. (2007). Sovereign Wealth Funds: State Investments on the Rise.

13. Dooley, M., Folkerts-Landau, D. \& Garber P. (2009). Bretton Woods II Still Defines the International Monetary Sytem. NBER Working Paper, 14731.

14. Dooley, M., Folkerts-Landau, D. \& Garber P. (2004). The revived Bretton Woods system. International Journal of Finance and Economics, 9, 307313.

15. Durdu, C.B., Mendoza E.G. \& Terrones M.E. (2009). Precautionary demand for foreign assets in sudden-stop economies: An assessment of the new mercantilism. Journal of Development Economics, 89(2), 194-209.

16. Eichengreen, B. \& Raco-Garcia R. (2006). The 
evolution of exchange rates regimes. Economic Policy.

17. Green, R. \& Torgerson T. (2007). Are High Foreign Exchange Reserves in Emerging Markets a Blessing or a Burden? Department of Treasury: Office of International Affairs, Occasional Paper No.6.

18. Griffith-Jones, S. \& Ocampo, J.A. (2010). Sovereign Wealth Funds. A Developing Country Perspective. Brussels: Foundation for European Progressive Studies .

19. Hall, S., Hondroyiannis, G., Swamy, P. \& Tavlas, G. (2009). Bretton-Woods System, Old and New, and the Rotation of Exchange-Rates Regimes. University of Leicester, Working Paper No.09/15.

20. Hutchison, M., Noy, I. \& Wang, L. (2010). Fiscal and monetary policies and the costs of sudden-stop. Journal of International Money and Finance, 29(6), 973-987.

21. IFSL. (2011). Sovereign Wealth Funds.

22. IMF. (2008). Sovereign Wealth Funds - A Work Agenda.

23. IMF. (2007). Global Financial Stability Report, Financial Market Turbulence. Causes, Consequences and Policies.

24. Lam, R.W. \& Rossi M. (2010) Sovereign wealth funds - investment strategies and financial distress. Journal of Derivatives \& Hedge Funds, 15(4), 304-322.

25. Machlup, F. (1966). The Need for Monetary Reserves, Banca Nazionale del Lavoro Quarterly Review, 5875.

26. Mateos y Lago, I., Duttagupta, R., Goyal, R. (2009). The Debate on International Monetary System. IMF Stuff Position Note, SPN/09/26.

27. Monitor Group (2011). Braving the New World: Sovereign Wealth Fund Investment in the Uncertain Times of 2010.

28. Nędzyński, K. (2003). Rola złota w polityce pieniężnej. Teoria monetarna $w$ modelu ekonomii podaży, Materiały i Studia. Zeszyt 168. Warsaw: Narodowy Bank Polski.

29. Ping, X. \& Chao, C. (2009). The Theoretical Logic of Sovereign Wealth Funds. Social Science Research Network.

30. Urban, D. (2010). Państwowe fundusze majątkowenowe wyzwanie dla nadzoru korporacyjnego, Contemporary Economics, 4(3), 39-48 .
31. Visco, I. (2010). Global Imbalances, Financial Crisis and the International Monetary System. World Economics, (11)(1), 69-82.

32. The World Bank Group. (2010.11.15). Retrieved from: www.worldbank.org

33. Sovereign Wealth Funds Institute. (11.06.25). Retrieved from: www.swfinstitute.org 